\title{
PELATIHAN SUMBER DAYA MANUSIA PELAYANAN DAN PENDAMPINGAN KORBAN KEKERASAN DALAM RUMAH TANGGA DI KABUPATEN SITUBONDO
}

\section{HUMAN RESOURCES TRAINING AND ASSISTANCE OF VICTIMS OF VIOLENCE IN HOUSEHOLDS IN SITUBONDO DISTRICT}

\author{
Sulistyaningsih \\ Fakultas Pertanian, Universitas Abdurachman Saleh Situbondo \\ Email: lis_sulistyaningsih@yahoo.com
}

Naskah diterima tanggal 20-06-2021, direvisi tanggal 27-11-2021, disetujui tanggal 03-12-2021

\begin{abstract}
Abstrak: Tujuan pengabdian ini adalah memberikan pencerahan dan pemahaman KDRT terhadap mayarakat utamanya pendamping sehingga dapat meningkatkan peran pendamping itu sendiri dan meminimumkan terjadinya kasus-kasus kekerasan. Luaran yang dihasilkan dari program ini meningkatkan pelayanan, pengetahuan, pemahaman serta penanganan tentang kasus Kekerasan Dalam Rumah Tangga. Pelatihan ini mendapat respon yang positif dari seluruh peserta.Selama pelatihan, peserta selalu datang tepat waktu dan sangat antusias dalam mendengarkan penjelasan dari para pengabdi. Para peserta juga sangat aktif dalam sesi diskusi dan banyak pertanyaan-pertanyaan yang dilontarkan. Pengetahuan mereka bertambah dengan adanya kegiatan ini dan sangat bermanfaat dalam penanganan kasus.
\end{abstract}

Kata Kunci: Pendampingan, Pelayanan, Kekerasan dalam rumah tangga

Abstract: The purpose of this service is to provide enlightenment and understanding of Domestic Violence to the community, especially the companion so that it can increase the role of the companion itself and minimize the occurrence of cases of violence. Output generated from this program Improve services, knowledge, understanding and handling of cases of Domestic Violence. This training received a positive response from all participants. During the training, participants always came on time and were very enthusiastic in listening to explanations from the servants. The participants were also very active in discussion sessions and many questions were asked. Their knowledge is increased by this activity and is very useful in handling cases.

Keywords: Assistance, Service, Domestic violence 
INTEGRITAS : Jurnal Pengabdian

Vol 5 No 2 Desember 2021

ISSN 2580- 7978 (cetak) ISSN 2615-0794 (online)

\section{PENDAHULUAN}

\section{Analisis Masalah}

Sebuah keluarga yang harmonis menjadi tempat yang paling aman dan menyenangkan bagi anggota keluarga, di sanalah mereka saling menyayangi dan melindungi. Namun pada kenyataannya tidak semua keluarga dapat berjalan secara harmonis seperti yang diharapkan, di mana anggota keluarga dapat merasakan kebahagiaan. Kondisi sebaliknya justru dirasakan yaitu tidak adanya kebahagiaan karena perasaan tertekan, rasa takut, rasa ketidak nyamanan dan lain sebagainya, karena adanya ketidak harmonisan dalam sebuah keluarga. Salah satu hal yang memicu ketidak harmonisan dalam keduanya adalah adanya kekerasan dalam keluarga.

Menurut Pasal 1 butir 1 UU RI No. 23 Tahun 2004 tentang Penghapusan Kekerasan Dalam Rumah Tangga, yang dimaksud dengan Kekerasan Dalam Rumah Tangga adalah:

"Setiap perbuatan terhadap seseorang terutama perempuan yang berakibat timbulnya kesengsaraan atau penderitaan secara fisik, seksual, psikologis dan/atau penelantaran rumah tangga termasuk ancaman untuk melakukan perbuatan yang memaksa atau perampasan kemerdekaan secara melawan hukum dalam lingkup rumah tangga."

Pemerintah kabupaten Situbondo melalui Dinas Pemberdayaan Perempuan dan Perlindungan Anak Situbondo (DPPPA), terus melakukan sosialisasi mulai tingkat desa, kecamatan dan sekolah serta organisasi perangkat daerah (OPD) untuk menekan angka kasus kekerasan terhadap perempuan dan anak, dan salah satunya bekerjasama dengan perguruan tinggi yang ada di kabupaten Situbondo. dalam rangka upaya perencanaan yang berkualitas untuk menurunkan angka kekerasan terhadap perempuan dan anak, serta meningkatkan capaian pembangunan perlindungan anak masih banyak membutuhkan ketersediaan data dan informasi statistik yang berkualitas (Anonymous, 2021). 
Data kekerasan dalam rumah tangga di Kabupaten Situbondo tahun 2020 sebanyak 62 kasus yang terdiri dari : KDRT 6 orang ; penganiayaan 5 0rang ; pencabulan 12 orang dan lain-lain 39 sehingga ( PPA Situbondo, 2020)

Pencegahan kasus KDRT perlu dilakukan karena akibat dari tindak kekerasan yang terjadi pada anak dan istri dalam rumah tangga ini dapat menimbulkan kesengsaraan atau penderitaan baik secara fisik maupun psikologis bagi korban. Kondisi tersebut tentunya sangat memprihatinkan, yang perlunya mendapatkan penanganan yang serius melalui upaya bersama yang melibatkan antara pihak pemerintah, masyarakat serta keluarga. Keterlibatan semua pihak dalam penanganan yang dilakukan secara optimal diharapkan akan memiliki dampak yang positif. Untuk karena itu diperlukan suatu kegiatan yang harus diadakan sepertisosialisasi dan pendampingan dalam rangka membantu penanganan dan meminimalisir kasus KDRT.

Tujuan pengabdian ini adalah memberikan pencerahan dan pemahaman KDRT terhadap mayarakat utamanya pendamping sehingga dapat meningkatkan peran pendamping itu sendiri dan meminimumkan terjadinya kasus-kasus kekerasan. Kekerasan Dalam Rumah Tangga hampir terjadi setiap hari bahkan setiap saat, banyaknya kasus tersebut ber variasi dan beberapa jenis kasus perkasus di kabupaten Situbondo yang variable memang sangat sensitif karena menggali kasus seperti kekerasan seksual, emosional atau psikologi, fisik, dan ekonomi pihak terkait yang menanganinya kedepan perlu mensosialisasikan lebih jauh dengan melibatkan beberapa unsur pembantu diantaranya adalah Psikolog dan Advokasi dan unsure perguruan tinggi.

\section{METODE}

Kerangka berpikir penanganan masalah dalam kegiatan ini diilustrasikan seperti pada gambar dibawah ini. Dari permasalahan yang muncul disusun berbagai alternatif untuk memecahkan masalah. Selanjutnya dari berbagai alternatif, dipilih alternatif 
yang paling mungkin dilaksanakan. Berdasarkan kerangka berpikir tersebut, maka metode dalam kegiatan ini adalah sebagai berikut:

\section{Permasalahan}

- Kurangnya Pemahaman KDRT sebagai kasus Publik

- Belum ada pendamping ditiap kecamatan yang inten dalam penanganan KDRT

- Pendamping yang sudah ada kegiatannya belum maksimal.

- Banyak masyarakat yang tidak tahu melapor kemana bila terjadi KDRT

\section{Metode Kegiatan}

- Ceramah dan diskusi tentang KDRT

- Ceramah dan diskusi tentang pendampingan

- Tanya jawab hubungan antara pelaporan dan penangan kasus

\section{Pemecahan Masalah}

- Meningkatkan pengetahuan tentang KDRT

- Meningkatkan pengetahuan tentang pentingnya pendampingan

- Meningkatkan kesadaran masyarakat dalam penanganan KDRT dan pelaporan kasus

- Meminimalisir terjadinya kasus KDRT
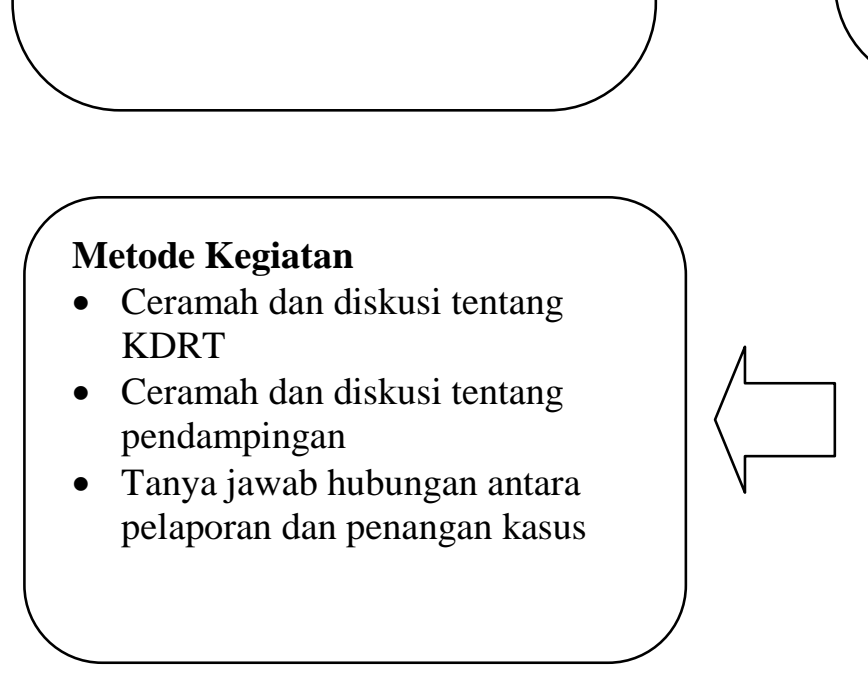

\section{Alternatif Pemecahan Masalah}

Meningkatkan pemahaman masyarakat tentang KDRT ,pelaporan, penanganan dan pendampingan

Gambar 1. Diagram Skematis Metode Kegiatan

\section{PEMBAHASAN}

Kegaiatan pengabdian ini bekerjasama dengan Dinas Pemberdayaan Perempuan dan Perlindungan Anak Situbondo (DPPPA) yang dilaksanakan pada tanggal 4-5 Desember 2020 bertempat di Ruang Rengganis Pemerintah Kabupaten Situbondo dan dihadiri oleh perwakilan dari tiap kecamatan sebanyak 17 orang dan Dinas terkait 3 orang. 
Pelaksanaan sangat antusias mengingat peserta ada yang baru mendapat pencerahan namun ada juga yang sudah pernah mengikuti kegiatan yang sama namun belum dilaksanakan secara maksimal . Pengetahuan yang di dapat dari sosialisasi dan pendampingan sangat bermanfaat sebagai masukkan dan gambaran mengenai penyelesaian kasus KDRT melalui jalur non litigasi. Mengingat tidak semua kasus harus diselesaikan secara hukum tapi lebih ditekankan pada penyelesaian kekeluargaan. Dengan adanya kegiatan pengabdian ini diharapkan terdapat peningkatan kesadaran masyarakat tentang pentingnya pencegahan terjadinya KDRT dan meningkatkan keluarga yang harmonis.

Dalam pelatihan tersebut banyak peserta yang bertanya tentang bagaimana penangan korban dan apakah kerahasiaan pelapor dan pendamping dijamin.selain itu juga diskusi tentang maraknya medsos yang justru banyak mendukung terjadinya perselingkuhan yang mengakibatkan ketidakharmonisan rumah tangga dimana situasi ini akan memicu terjadinya pertengkaran-pertengkaran yang ujung-unjungnya adalah terjadinya kekerasan fisik. Dan peserta juga bertanya tentang akibat dari adanya pembelajaran daring yang saat ini hampir semua sekolah melaksanakan kegiatan belajarnya menggunakan daring.

Memang dalam penanganan maslah KDRT sangat dibutuhkan kesabaran mengingat bahwa masalah ini menurut sebagian besar masyarakat merupakan maslah yang sifatnya internal, mereka masih beranggapan masalah tersebut bukan ranah public oleh karena itu sebagai relawan pendamping memang dibutuhkan pendekatanpendekatan yang lebih kekeluargaan sebab sebisa mungkin penyelesaian kasus tidak selalu ke ranah hukum.

Foto-Foto kegiatan pelaksanaan pengabdian sebagai berikut: 


\section{INTEGRITAS : Jurnal Pengabdian}

Vol 5 No 2 Desember 2021

ISSN 2580- 7978 (cetak) ISSN 2615 - 0794 (online)

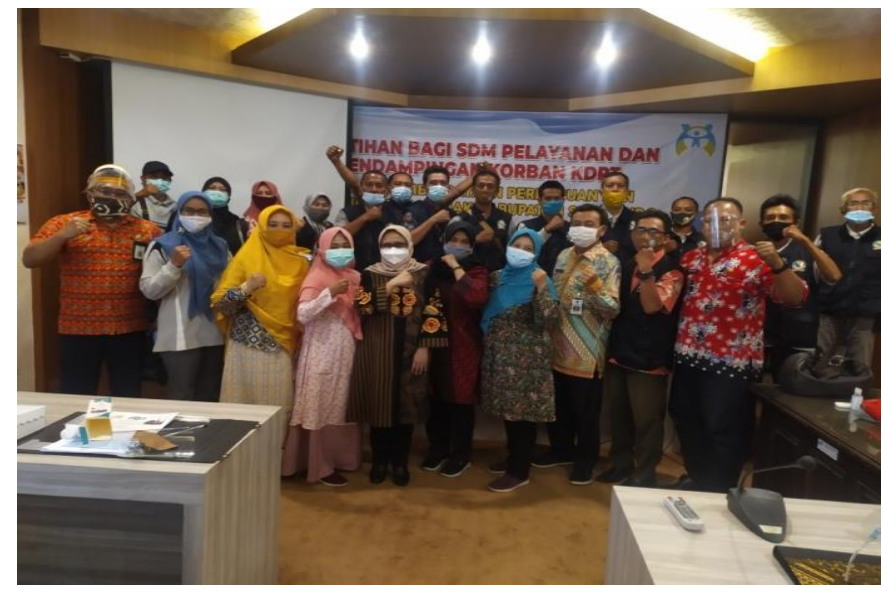

Gambar 2. Foto Bersama Peserta Pelatihan Sumber Daya Manusia Pelayanan dan Pendampingan Korban Kekerasan Dalam Rumah Tangga Di Kabupaten Situbondo

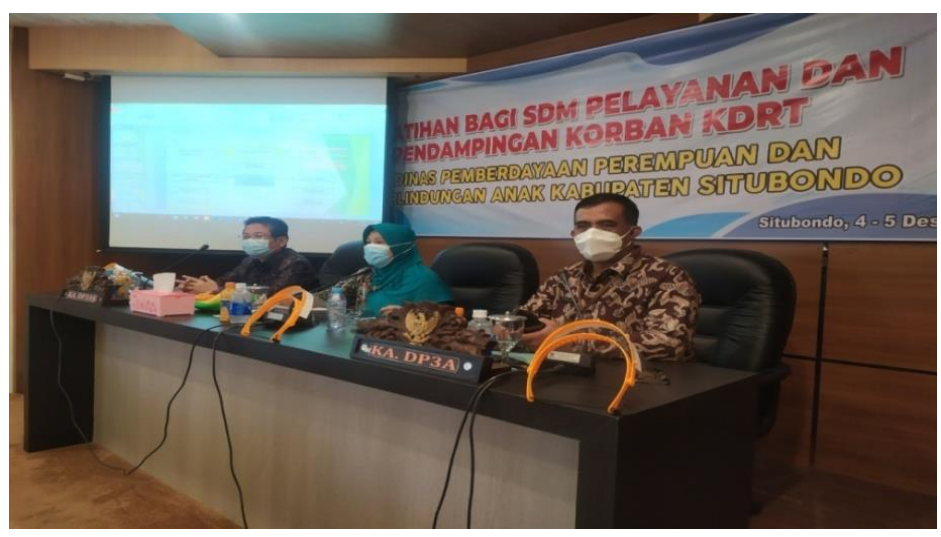

Gambar 3. Bersama Kepala Dinas Pemberdayaan Perempuan dan Perlindungan Anak Situbondo (DPPPA) H.Imam Hidayat S.Kep.Ns.MM.Kes

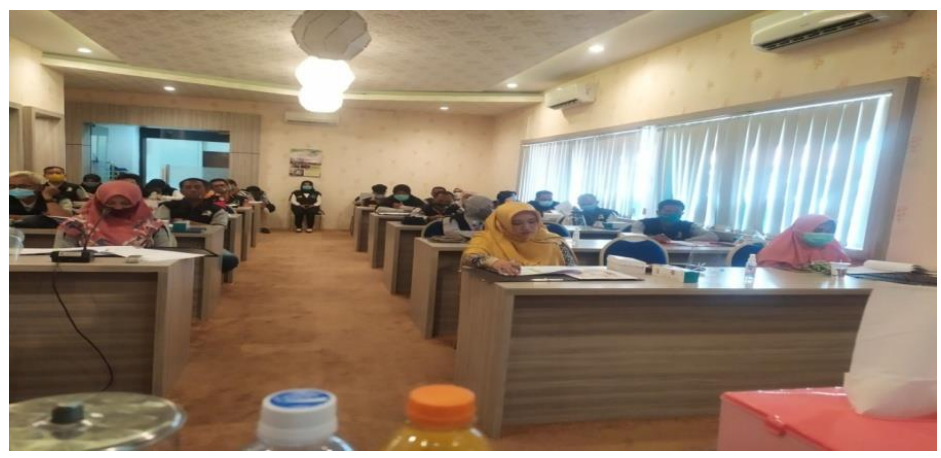

Gambar 4. Peserta Pelatihan sedang mendengarkan dan menyimak materi yang disampaikan oleh Narasumber 
INTEGRITAS : Jurnal Pengabdian

Vol 5 No 2 Desember 2021

ISSN 2580- 7978 (cetak) ISSN 2615-0794 (online)

\section{KESIMPULAN}

1. Kegiatan Pelatihan SDM Pelayanan dan Pendampingan Korban KDRT Di Kabupaten Situbondo berjalan dengan lancar.

2. Peserta dengan semangat mengikuti pelatihan sampai akhir.

3. Peserta menginginkan adanya kegiatan yang berkelanjutan jadi tidak hanya sampai disini.

\section{DAFTAR PUSTAKA}

------- https://memontum.com/139373-dpppa-situbondo-terapkan-pengaduan-kdrtsecara-online diunduh, 7 April 2021

http://eprints.ums.ac.id/46287/3/BAB\%20I.pdf diunduh 2 Desember 2020

UU RI No. 23 Tahun 2004 tentang Penghapusan Kekerasan Dalam Rumah Tangga.

PPA (Perlindungan Perempuan dan Anak), Kabupaten Situbondo, 2020. 